\title{
CONTRIBUTION OF LITTER ON DIFFERENT GEOMORPHOLOGICAL CONDITIONS IN THE ATLANTIC FOREST - STATE OF RIO DE JANEIRO, BRAZIL.
}

\author{
Victória Maria Monteiro Mendonça ${ }^{1 *}$, Gilsonley Lopes dos $\operatorname{Santos}^{2}$, Marcos Gervasio Pereira $^{3}$, \\ Carlos Eduardo Gabriel Menezes ${ }^{4}$
}

\footnotetext{
${ }^{1 *}$ Postgraduate Program in Environmental and Forest Science, Rural Federal University of Rio de Janeiro, Seropédica, state of Rio de Janeiro, Brazil - e-mail: viic_monteiro@hotmail.com

${ }^{2}$ Postgraduate Program in Environmental and Forest Science, Rural Federal University of Rio de Janeiro, Seropédica, state of Rio de Janeiro, Brazil - e -mail: leylopes85@hotmail.com

${ }^{3}$ Department of de Soil, Institute of Agronomy, Rural Federal University of Rio de Janeiro, Seropédica, state of Rio de Janeiro, Brazil - e mail: mgervasiopereira01@gmail.com

${ }^{4}$ Federal Instite of Education, Science and Technology - RJ, Campus Nilo Peçanha, Pinheiral, state of Rio de Janeiro, Brazil - e -mail: carlos.menezes@ifrj.edu.br
}

Received for publication: 04/08/2017 - Accepted for publication: 12/18/2018

\begin{abstract}
Resumo
Aporte de serapilheira sobre diferentes condições geomorfológicas em floresta estacional semidecidual submonta-rja. A deposição da serapilheira no piso florestal é influenciada pelos fatores bióticos e abióticos nos quais os fragmentos florestais estão inseridos, sendo esta uma das maiores fontes de nutrientes para o solo. Assim, o objetivo deste estudo foi avaliar a influência da variação das condições de relevo (pedoforma) no aporte de serapilheira e nos teores de nutrientes num fragmento de Floresta Estacional Semidecidual Submontana, Pinheiral (RJ). Foram selecionadas duas pedoformas adjacentes com relevo do tipo convexa e côncava, sendo essas divididas em mini sítios (MS) quanto à variação da declividade e do gradiente topográfico. Foram instalados 5 coletores cônicos com área $0,2834 \mathrm{~m}^{2} \mathrm{em}$ cada MS, totalizando 30 coletores. As coletas da serapilheira foram realizadas a cada 30 dias no decorrer de um ano. O material retido nos coletores foi triado quanto às frações: folhas, galhos, material reprodutivo e outros, para avaliar a proporção de cada fração na produção de serapilheira e os teores de nutrientes da fração folhas. O aporte e o teor de nutrientes da serapilheira são influenciados pelo tipo de pedoforma e estações do ano. Observou-se o maior aporte na estação seca, nos MS inferiores e médios das pedoformas, e os maiores teores nutricionais ocorrentes na pedoforma convexa durante a estação chuvosa.
\end{abstract}

Palavras-chave: pedoforma, ciclagem de nutrientes, fragmentos florestais.

\begin{abstract}
The deposition of leaf litter on the forest floor is influenced by biotic and abiotic factors where forest fragments are inserted, which is a major source of nutrients to the soil. The objective of this study was to evaluate the influence of the change in relief conditions (landform) in leaf litter contribution and nutrient content in a Submontane Seasonal Semi-deciduous Forest in Pinheiral (state of Rio de Janeiro, Brazil). It was selected two adjacent landforms with convex and concave relief type and they divided into small sites (SS), obeying the variation of the slope and topographic gradient. Five conic collectors with an area of $0.2834 \mathrm{~m}^{2}$ were installed in each SS, totaling 30 collectors. The collections of leaf litter were carried out every 30 days during a year. The material retained in the traps was separated as the fractions; leaves, twigs, reproductive and other material to assess the proportion of each fraction in the leaf litter production and nutrient content of the fraction leaves. The contribution and nutrient content of litter are influenced by the type of landform and seasons of the year. The highest contribution was observed in the dry season, in the lower and middle SS of the landforms, and the highest nutrient levels occurred in the convex landform during the rainy season.

Key-words: landform, nutrient cycling, forest fragments.
\end{abstract}

\section{INTRODUCTION}

Litter consists of plant origin materials (leaves, branches, bark and reproductive material) and animal origin materials (fecal material and animal residues) accumulated on the forest floor (CUNHA NETO et al., 2013). Its deposition on the forest floor occurs throughout the year, and this production is influenced by the biotic and abiotic factors, such as vegetation type, successional stage, deciduousness, altitude, relief, rainfall, temperature, luminosity, soil characteristics and water availability (GODINHO et al., 2013). 
Moreover, litter indicates the productive capacity of the forest, relating the available nutrients to the nutritional needs of each tree species, and it is the largest source of nutrients in the soil. The accumulation of nutrients in the soil, together with the nutritional needs of plants, compose the nutrient cycling process, responsible for the exchange of mineral elements between living beings and the environment. It is therefore fundamental in the relationship between vegetation and soil (PINTO et al., 2008).

After deposition of the material on the forest floor, its accumulation at the soil surface will be regulated by its rate of decomposition. Through decomposition litter releases nutrients to the soil which are essential for the development of vegetation, and this process plays an elementary role in the cycling of nutrients (PEREIRA et al., 2008).

Deposition, accumulation and decomposition of the litter-forming material occurs in a differentiated way, due to the many specific topographic characteristics and soil classes that lead to the formation of microenvironments in the landscape (SANTOS et al., 2017).

According to Santos et al. (2017), environments with diverse topographic characteristics influence the biotic and abiotic attributes of a given ecosystem. The interaction between several factors such as constituent species, climate, soils, disturbances occurring in the area, successional aspects of the forest result in vegetation structure and can change the depositional dynamics of the litter (SCORIZA; PIÑ-RODRIGUES, 2014).

In Brazilian ecosystems, there are two basic patterns for annual deposition of litter. In the first pattern, there is a greater deposition in the dry season (Amazon ecosystems, Mesophytic Forests and Cerrado forests), and in the second one there is an increase in litter deposition intensity in the wet season (Atlantic forests and Restingas) (SCORIZA, PIÑA-RODRIGUES, 2014).

The contribution of litter is also influenced by the variation of topographic conditions, and even in similar climatic conditions the forests present diverse floristic and edaphic characteristics (EISENLOHR et al., 2013). Thus, above-ground biomass and litter deposition tend to decrease with altitude due to the limited soil nutrient availability, which affects primary productivity (MOSER et al., 2011).

Among the topographic variables capable of interfering with the floristic structure of a region, those related to relief, such as topography and geomorphology, stand out. The terrain format affects vegetation patterns within the same climatic region, and in mountainous areas these patterns are closely related to ground patterns at the landform level (HARA et al., 1996).

According to Troeh (1965), landforms can be classified in: linear, concave and convex, presenting some variations. In this classification, the curvature is indicative of the terrain evolution degree and weathering degree. Studies, such as Schmiat et al. (2003), show that the curvature of a slope is directly related to soil water content, convergent/divergent flow, rate of erosion/deposition, transport and accumulation of minerals and organic material. In this way, the landform type can influence the vegetation and consequently the contribution of litter.

Thus, the objective of this study was to evaluate the influence of the change in relief conditions (landform) in litter contribution and nutrient content in a Submontane Seasonal Semi-deciduous Forest, located in Pinheiral (state of Rio de Janeiro, Brazil).

\section{MATERIAL AND METHODS}

\section{Location and characterization of the study area}

The study was carried out in the municipality of Pinheiral, state of Rio de Janeiro, in the region of the Middle Paraíba Fluminense, in the sub-basin of the Cachimbal river, located between latitudes $22^{\circ} 29^{\prime} 03^{\prime \prime} \mathrm{S}$ and $22^{\circ} 35^{\prime} 27^{\prime \prime} \mathrm{S}$ and between the longitudes $43^{\circ} 54^{\prime} 49^{\prime \prime} \mathrm{W}$ and $44^{\circ} 04^{\prime} 05^{\prime \prime} \mathrm{W}$.

The climate of the region is classified as Am - rainy tropical climate with dry winter and Cwa - temperate climate of dry winter and rainy summer, according to the classification of Köppen (ALVARES et al., 2013), with average annual temperature of $21^{\circ} \mathrm{C}$ and annual precipitation around 1,300 $\mathrm{mm}$ (DINIZ et al., 2015). 


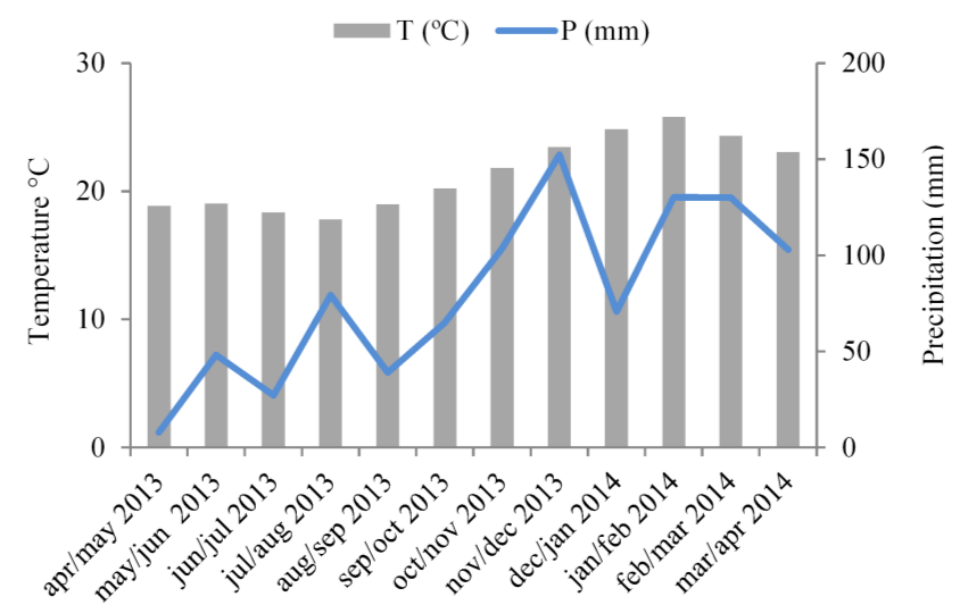

Figura 1: Médias mensais de temperatura e de precipitação na sub-bacia do Ribeirão Cachimbal, no período de abril de 2013 a abril de 2014. Dados da estação meteorológica do Instituto Federal de Educação, Ciência e Tecnologia do Rio de Janeiro, "Campus Pinheiral".

Figure 1: Monthly averages of temperature and precipitation in the sub-basin of Ribeirão Cachimbal, from April 2013 to April 2014. Data from the meteorological station of the Federal Institute of Education, Science and Technology of Rio de Janeiro, "Campus Pinheiral".

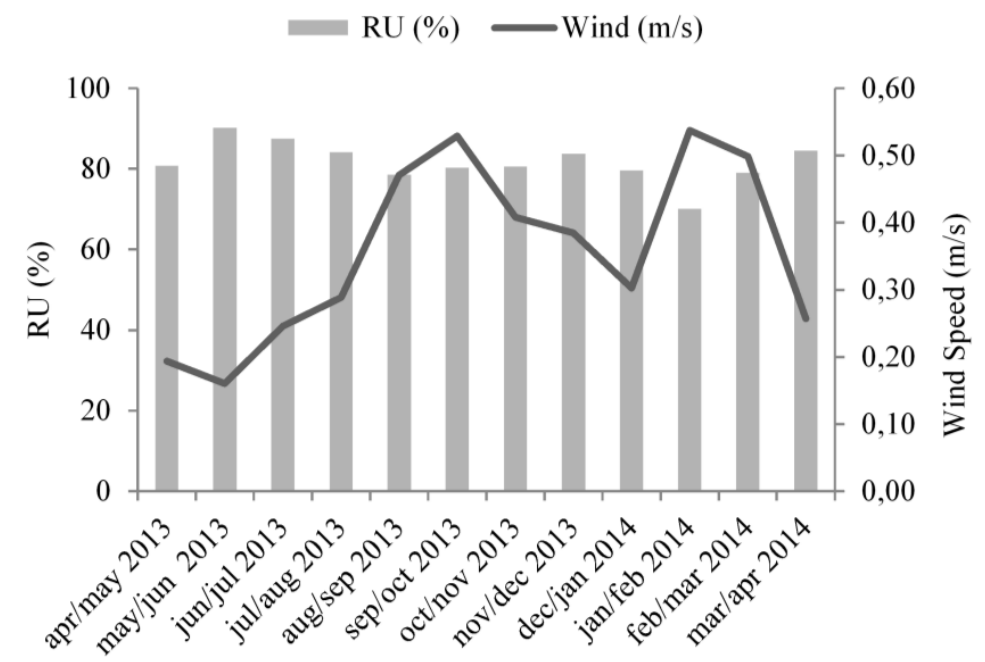

Figura 2: Médias mensais de umidade e velocidade dos ventos na sub-bacia do Ribeirão Cachimbal, no período de abril de 2013 a abril de 2014. Dados da estação meteorológica do Instituto Federal de Educação, Ciência e Tecnologia do Rio de Janeiro, "Campus Pinheiral".

Figure 2: Monthly means of humidity and wind speed in the sub-basin of Ribeirão Cachimbal, from April 2013 to April 2014. Data from the meteorological station of the Federal Institute of Education, Science and Technology of Rio de Janeiro, "Campus Pinheiral".

The region is part of the ecological domain of the Atlantic Forest, whose original vegetation was classified as Semidecidual Submontane Seasonal Forest (IBGE, 2012). The study area soils were classified according to Menezes et al. (2010) as typical Cambisol Haplic Tb Distrophic.

Collection and processing of litter

Two landforms (convex and concave) were selected on a forest fragment in secondary regeneration stage (CONAMA, 1996). Each landform was segmented in three environments (Figure 3) called small sites (SS), differentiated in terms of topographic gradient and slope, totaling six small sites (Table 1). 


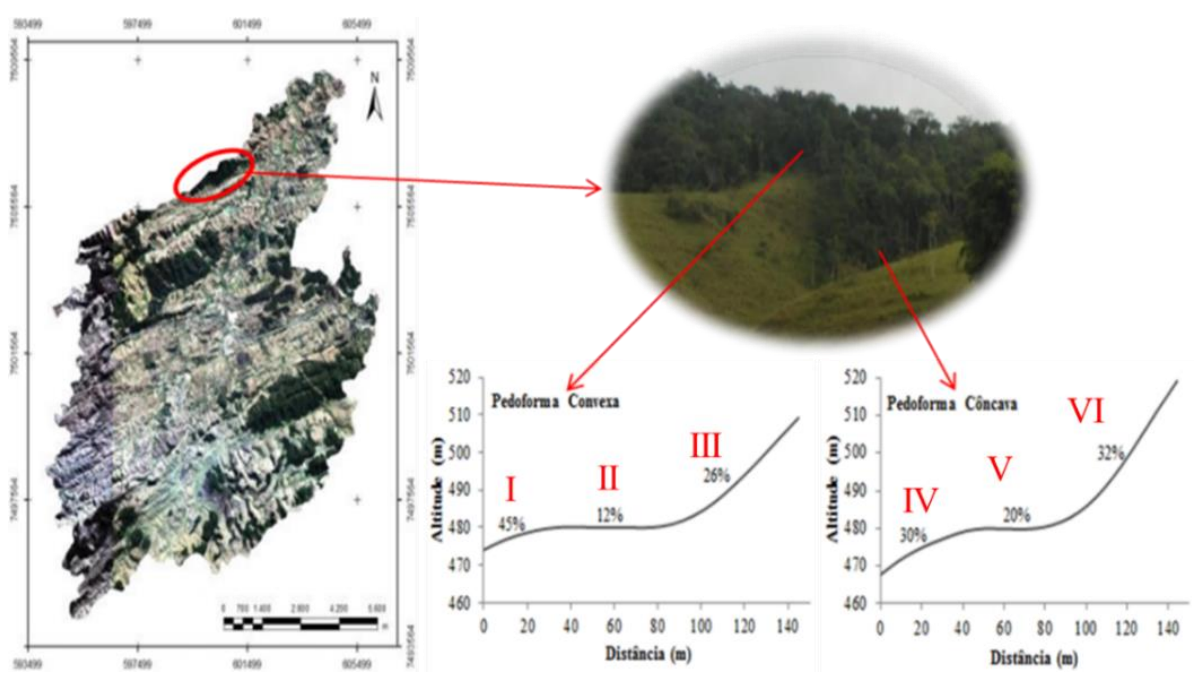

Figura 3: Localização e segmentação das pedoformas (convexa e côncava) em mini sítios (I, II, III, IV, V e VI) na sub-bacia do ribeirão Cachimbal, Pinheiral-RJ. Fonte; Adaptado de Santos et al. (2016).

Figure 3: Localization and segmentation of landforms (convex and concave) in small sites (I, II, III, IV, V and VI) in Cachimbal creek sub-basin, Pinheiral-RJ. Source: Adapted from Santos et al. (2016).

Tabela 1: Caracterização dos mini sítios nas pedoformas convexa e côncava em Floresta Estacional Semidecidual Submontana, Pinheiral-RJ

Table 1: Characterization of the small sites in the convex and concave landforms in Semidecidual Seasonal Forest Submontana, Pinheiral-RJ

\begin{tabular}{c|c|c|c|c|c|c}
\hline SS & Landform & $\begin{array}{c}\text { Position in } \\
\text { the } \\
\text { Landscape }\end{array}$ & $\begin{array}{c}\text { Average } \\
\text { Declivity (\%) }\end{array}$ & $\begin{array}{c}\text { Average } \\
\text { Altitude (m) }\end{array}$ & Width (m) & Length (m) \\
\hline I & Convex & inferior & 45 & 520 & 20 & 33 \\
II & Convex & intermediary & 12 & 530 & 20 & 30 \\
III & Convex & superior & 26 & 550 & 20 & 72 \\
IV & Concave & inferior & 30 & 485 & 20 & 45 \\
V & Concave & intermediary & 20 & 590 & 20 & 30 \\
VI & Concave & superior & 32 & 500 & 20 & 72 \\
\hline
\end{tabular}

Legend: SS: small site; I, II and III - SS with variation of the topographic gradient and the slope in the convex landform; IV, V and VI - SS with variation of the topographic gradient and slope in the concave landform.

In order to evaluate the contribution of the litter, 5 conical collectors with an area of $0.2834 \mathrm{~m}^{2}$ were installed in each SS in April 2013, totaling 30 collectors in all studied area, made with $1 \mathrm{~mm}$ nylon screen, and fixed at a height of 1.0 meters above the ground surface. The litter collections were carried out in the period of one year, within the interval between May 2013 to April 2014.

The material deposited in the collectors was bagged, identified and taken monthly to the Environmental Indicators Laboratory (LIEA), in the Department of Soils of the Institute of Agronomy of UFRRJ. For each collection the material was sorted regarding to the fractions: leaves ( $\mathrm{L}=$ limbs and petioles), branches (B), reproductive material $(\mathrm{RM}=$ fruits, flowers and seeds $)$ and others $(\mathrm{O}=$ not identified organic residues, excrements of animals, among others), in order to evaluate the ratio of each fraction in litter production. The fractions were oven dried at $65^{\circ} \mathrm{C}$ with forced circulation for 72 hours, when they reached constant weight, and they were weighed for quantification of the dry mass (SCORIZA et al., 2012).

The total monthly litter contribution of each landform and SS was determined from the collector's arithmetic mean. The contribution for the dry period (April to September) and for the rainy season (October to March) were also determined. From these data, the production of litter was estimated based on the following equation, modified according to LOPES et al. (2002): 


$$
P S=\left(\frac{\left(\sum P M \times 10.000\right)}{A c}\right)
$$

in which: $\mathrm{LP}=$ Litter production $\left(\mathrm{kg} \cdot \mathrm{ha} \mathrm{a}^{-1} \cdot \mathrm{year}^{-1}\right), \mathrm{MP}=$ Monthly litter production $\left(\mathrm{kg} \cdot \mathrm{ha} \cdot{ }^{-1} \cdot \mathrm{month}^{-1}\right)$ and $\mathrm{cA}=$ Collector area $\left(\mathrm{m}^{2}\right)$.

To evaluate the contribution of nutrients, the $\mathrm{F}$ fraction was selected because it is the one that contributes the most to litter production. At each collection, the leaf fraction after drying and grinding was subjected to sulfur digestion. The chemical analyzes were carried out to determine the total N, P and K contents. The N contents were obtained by wet oxidation in steam distillation; $\mathrm{P}$ by spectrophotometry; and $\mathrm{K}$ by flame photometry (TEDESCO et al., 1995).

Statistical analysis of data

The data were submitted to normality analysis (Shapiro Wilk test, 5\%) and homogeneity of error variance (Levene test, 5\%). As the data did not meet these assumptions, a non-parametric analysis (Kruskall-Wallis test, $5 \%$ ) was performed through the Action 2.5 statistical package.

\section{RESULTS}

The concave and convex landforms showed significant differences between them in relation to the contribution of the litter fractions. The fractions L and RM were the ones with greater contribution in the convex landform and the fractions $\mathrm{B}$ and $\mathrm{O}$ in the concave landform (Table 2).

Tabela 2: Aporte e teor de nutrientes de serapilheira em diferentes pedoformas com Floresta Estacional Semidecidual Submontana, Pinheiral-RJ.

Table 2: Intake and litter nutrient content in different landforms with Semideciduous Forest Submontane, Pinheiral-RJ.

\begin{tabular}{|c|c|c|c|c|c|c|c|}
\hline \multirow{3}{*}{ Landform } & \multicolumn{4}{|c|}{ Litter Fractions } & \multicolumn{3}{|c|}{ Nutrient Fraction Leaves } \\
\hline & $\mathrm{L}$ & RM & $\mathrm{B}$ & $\mathrm{O}$ & $\mathrm{N}$ & $\mathrm{P}$ & $\mathrm{K}$ \\
\hline & \multicolumn{4}{|c|}{ 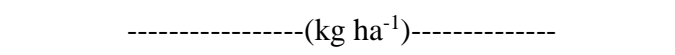 } & \multicolumn{3}{|c|}{ 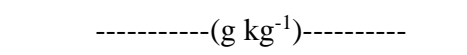 } \\
\hline Convex & 520.08 & 60.91 & 113.51 & 74.41 & $17.36 \mathrm{a}$ & $0.59 \mathrm{~b}$ & 5.53 \\
\hline Concave & 506.74 & 56.61 & 161.05 & 77.06 & $15.36 \mathrm{~b}$ & $0.66 \mathrm{a}$ & 5.56 \\
\hline
\end{tabular}

Legend: L, leaves; RM, reproductive material; B, branches; O, others; N, nitrogen; P, phosphorus; K, potassium; Means followed by different letters, in the same column, differ from each other at the $5 \%$ probability level by the Kruskal-Wallis test; Columns without letters did not have significant differences.

Regarding the mini sites, a greater contribution of the $\mathrm{L}$ fraction was observed in the lower and middle SS of both landforms (Table 3). For the B fraction, higher values of material deposited in the SS of the lower third (I) and the middle third (II) of the convex landform were quantified, as well as in the upper third of the concave landform (VI).

Tabela 3: Aporte e teor de nutrientes de serapilheira em diferentes mini sítios com Floresta Estacional Semidecidual Submontana, Pinheiral-RJ.

Table 3: Intake and litter nutrient content in different small sites with Semideciduous Forest Submontane, Pinheiral-RJ.

\begin{tabular}{ccccccccc}
\hline \multirow{2}{*}{ Small Site } & \multicolumn{4}{c}{ Litter Fractions } & \multicolumn{3}{c}{ Nutrient Fraction Leaves } \\
\cline { 2 - 8 } & & $\mathrm{L}$ & $\mathrm{RM}$ & $\mathrm{B}$ & $\mathrm{O}$ & $\mathrm{N}$ & $\mathrm{P}$ & $\mathrm{K}$ \\
\hline I & $510.76 \mathrm{ab}$ & 28.65 & $112.93 \mathrm{ab}$ & 83.46 & $16.34 \mathrm{ab}$ & $0.50 \mathrm{c}$ & $4.97 \mathrm{~b}$ \\
II & $552.71 \mathrm{a}$ & 88.44 & $138.10 \mathrm{ab}$ & 78.98 & $17.60 \mathrm{a}$ & $0.56 \mathrm{bc}$ & $5.84 \mathrm{ab}$ \\
III & $496.75 \mathrm{ab}$ & 65.64 & $89.51 \mathrm{~b}$ & 79.44 & $18.13 \mathrm{a}$ & $0.70 \mathrm{a}$ & $5.78 \mathrm{ab}$ \\
IV & $598.99 \mathrm{a}$ & 42.89 & $91.87 \mathrm{~b}$ & 63.43 & $17.65 \mathrm{a}$ & $0.63 \mathrm{ab}$ & $4.64 \mathrm{~b}$ \\
V & $534.80 \mathrm{ab}$ & 72.74 & $184.32 \mathrm{~b}$ & 85.85 & $15.29 \mathrm{~b}$ & $0.60 \mathrm{bc}$ & $4.96 \mathrm{~b}$ \\
VI & $386.46 \mathrm{~b}$ & 54.21 & $206.95 \mathrm{a}$ & 81.88 & $13.14 \mathrm{c}$ & $0.74 \mathrm{a}$ & $7.07 \mathrm{a}$ \\
\hline
\end{tabular}

FLORESTA, Curitiba, PR, v. 49, n. 3, p. 373 - 382, jul/set 2019.

Mendonça, V. M. M. et.al.

ISSN eletrônico 1982-4688

DOI: $10.5380 /$ rf.v49 i3.51657 
Legend: L, leaves; RM, reproductive material; B, branches; O, others; N, nitrogen; P, phosphorus; K, potassium; Means followed by different letters, in the same column, differ from each other at the $5 \%$ probability level by the Kruskal-Wallis test; Columns without letters did not have significant differences.

The contribution of litter and the nutrient contents found in the landforms were evaluated according to temperature variability and the study period monthly rainfall average. The contribution of litter presented a dynamic associated with the meteorological variables. It was possible to observe a direct influence of meteorological factors variation in the contribution. Figure 4 shows the highest contribution values of L, B, RM and $\mathrm{O}$ fractions at the end of the dry season and the beginning of the rainy season.
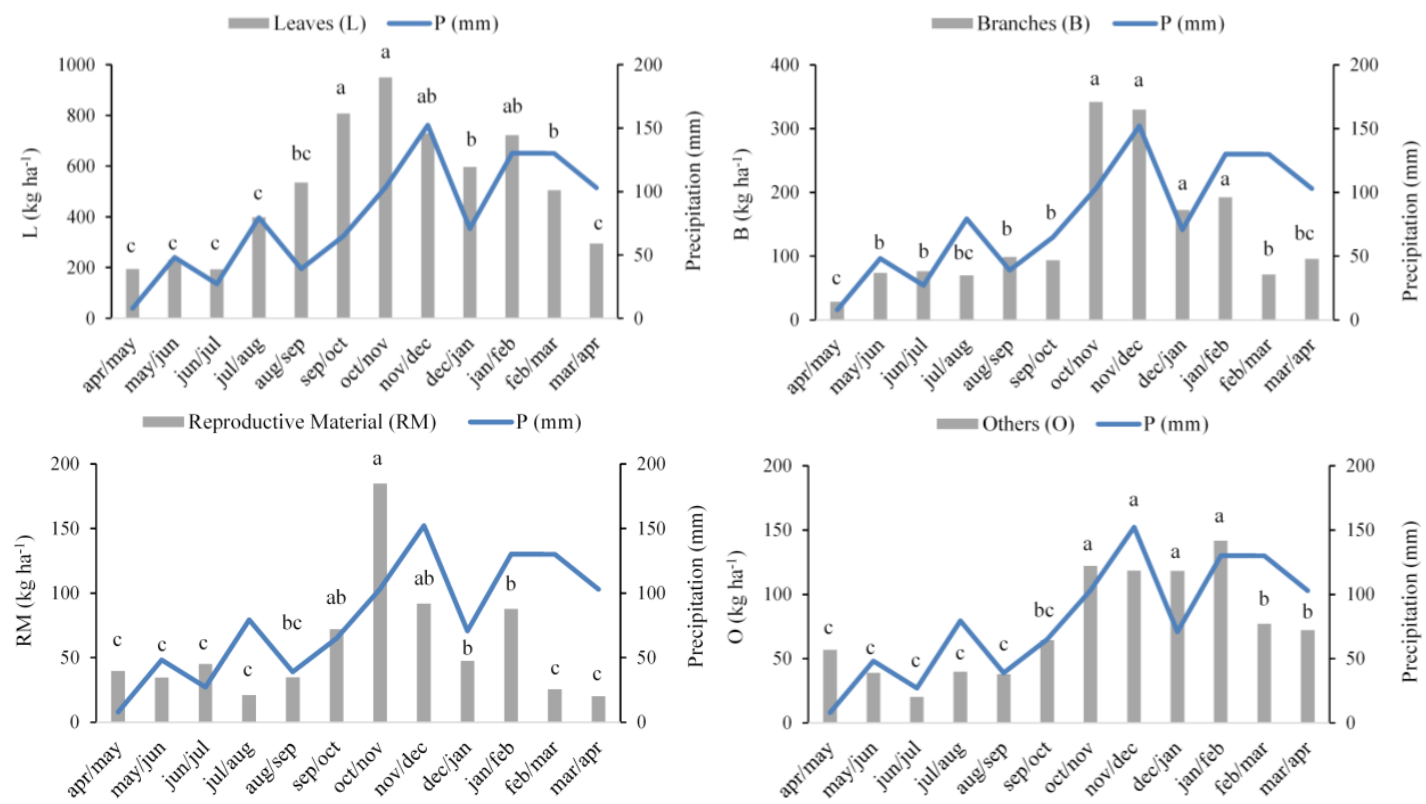

Figura 4: Valores médios mensais aportados das frações F, G, MR e O e da precipitação pluviométrica acumulada mensalmente, no período de abril de 2013 a abril de 2014.

Figure 4: Monthly average values of L, B, RM and $\mathrm{O}$ fractions and the monthly accumulated rainfall, from April 2013 to April 2014.

The estimated annual contribution was $10.98 \mathrm{Mg} \mathrm{ha}^{-1}$. For $\mathrm{L}$ and $\mathrm{RM}$ fractions the highest contribution was observed in the sep./oct. and oct./nov. periods, at the end of the dry season (Figure 4). The B and O fractions presented a larger contribution in the period of Oct./Nov. to Jan./Feb.

Regarding the litter's nutrient contents (leaves fraction), significant differences were observed between the landforms. The highest levels of $\mathrm{N}$ were verified in the convex, the highest levels of $\mathrm{P}$ were quantified in the concave landform and for $\mathrm{K}$ contents no differences were verified (Table 2).

In relation to the nutrient contents, a differentiated distribution was observed in relation to the SS. N contents were higher in I, II, III and IV, presenting a regular distribution along the topographic gradient of the convex landform up to the lower third of the concave landform (Table 3). On the other hand, for the levels of $\mathrm{P}$ and $\mathrm{K}$ the highest values were found in SS III and VI that are inserted in the upper regions of both landforms (Table 3).

When considering the influence of meteorological variables on the nutrient content of the $\mathrm{L}$ fraction, a pattern contrary to the one of the intake was observed, in which the highest nutrient contents were observed at the end of the rainy season and at the beginning of the dry season, as shown in figure 5. 


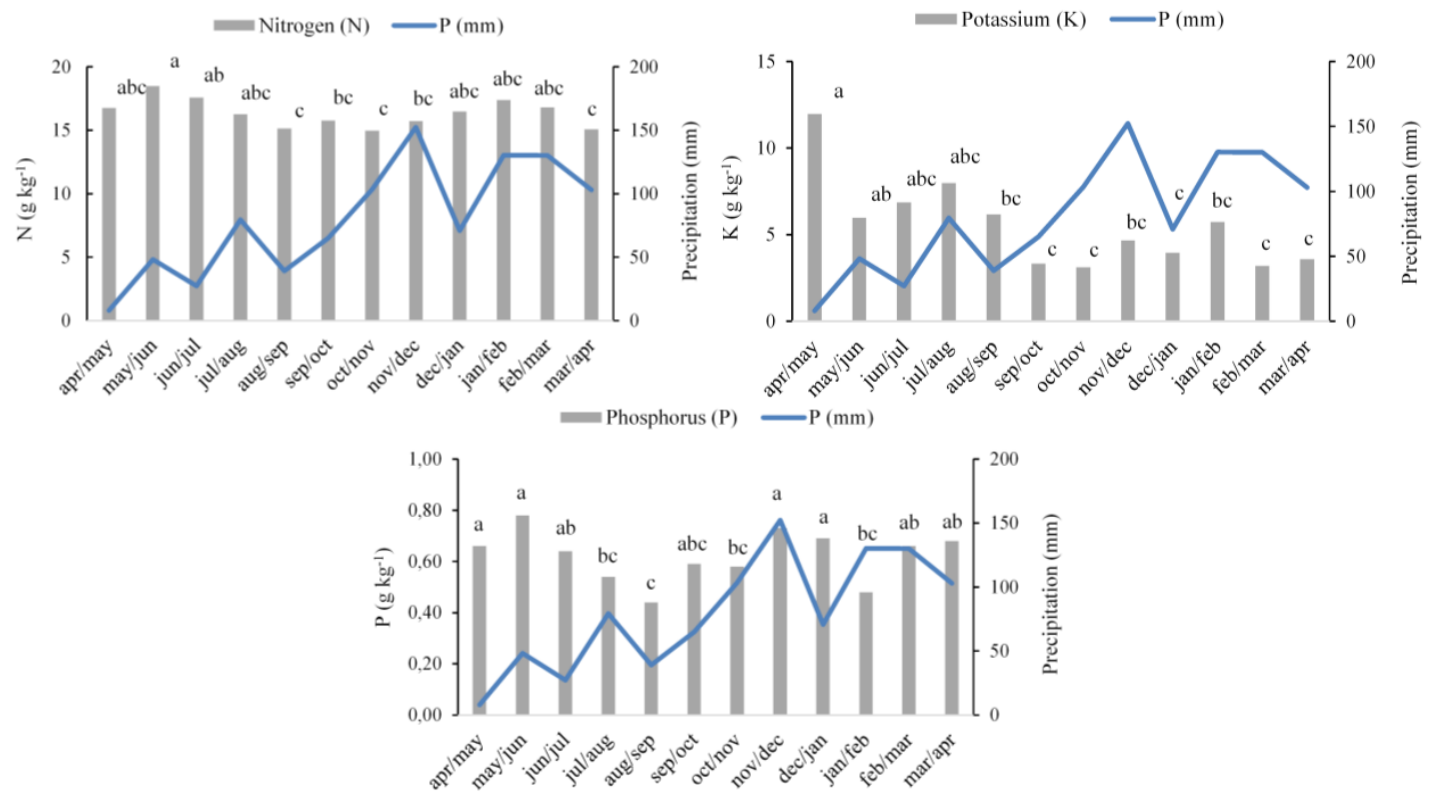

Figura 5: Valores médios mensais dos teores de nutrientes (N, P e K) da fração folhas aportada e da precipitação pluviométrica acumulada mensalmente, no período de abril de 2013 a abril de 2014.

Figure 5: Mean monthly values of nutrient contents (N, P and K) of the leaf fraction contributed and the monthly accumulated rainfall, from April 2013 to April 2014.

By analyzing the nutrient contents of fraction L, there was an annual return of $97.57 \mathrm{~kg} \mathrm{ha}^{-1}$ of N; $3.74 \mathrm{~kg}$ $\mathrm{ha}^{-1}$ of $\mathrm{P}$ and $29.80 \mathrm{~kg} \mathrm{ha}^{-1}$ of $\mathrm{K}$ to the soil.

$\mathrm{N}$ and $\mathrm{K}$ levels were higher in the periods of Apr./May and May/Jun., in both landforms, being these in the end of the rainy season and beginning of the dry season (Figure 5). On the other hand, the levels of $\mathrm{P}$ were different, with the highest content observed in the periods from Apr./May to May/Jun and from Nov./Dec. to Dec./Jan., as can be seen in figure 5 .

\section{DISCUSSION}

The greatest contribution of the fractions L and RM was observed in the convex landform in relation to the concave landform, which is associated with the variations of landforms microclimatic conditions. Since the convex landform is a site with a higher incidence of solar radiation and winds, it results in a drier environment, as observed by Santos et al. (2017). Studies such as Villa et al. (2016), evaluating the contribution of litter in environments with forest cover, verified that the highest values occurred at the end of long periods of drought. The values were influenced by diversity, plant structure and environmental influences (temperature and rainfall).

Regarding the SS, the highest values of the L fraction occurred in the inferior SS that are attributed to the greater vegetation development and the microclimatic conditions of the environments. These elements are favorable to higher leaf production and leaf input (Table 3). Basnet (1992) corroborates the diversity of microclimates in the topographic gradient, varying according to the type of soil, humidity regimes, geological formation and altitude, being answered by the plants through the variation of the leaf area and difference of production in compensation to the amount of energy incident.

In relation to the quantified values for the B fraction (Table 3), SS VI stood out and could be directly related to a higher incidence of winds associated with already dead tree species, leaving the system in the concave landform (observed in the field).

The effect of climate variability on litter supply was also observed by Antoneli and Franceschini (2014), in the Mixed Ombrophilous Forest, where they verified that the greatest contribution occurred in the summer, which was associated to the lower vegetative growth in the winter, due to influence of the climatic variables: lower rainfall, lower temperature and lower evaporation.

Studies such as Cunha et al. (1993), in Deciduous Seasonal Forest (Santa Maria/state of Rio Grande do Sul), observed that the litter deposition pattern because of rainfall presented lower litter deposition in the autumn (March, April and May) and the highest occurred between the end winter and late spring (August to November).

FLORESTA, Curitiba, PR, v. 49, n. 3, p. 373 - 382, jul/set 2019.

Mendonça, V. M. M. et.al.

ISSN eletrônico 1982-4688

DOI: $10.5380 /$ rf.v49 i3.51657 
Analyzing the contribution of litter and nutrients in forest restoration area with different spacings in the city of Seropédica/state of Rio de Janeiro, Villa et al. (2016) found the highest contribution values in the dry season, but without synchrony with the spacings. Attributing their results to the genetic characteristics of the species, as well as to the deciduity, environmental influences (temperature and rainfall) and the growth rate of the plants.

Machado et al. (2015), in areas of the same region (Pinheiral - state of Rio de Janeiro), where the areas studied were classified as: Floresta estágio inicial; Floresta estágio médio; Floresta estágio avançado, observed an annual litter contribution of: $7,47 \mathrm{Mg} \mathrm{ha}^{-1} ; 8,96 \mathrm{Mg} \mathrm{ha}^{-1}$ e $14,7 \mathrm{Mg} \mathrm{ha}^{-1}$ respectively, pattern similar to the one found in this study.

The quantification of the higher contribution of the L and RM fractions at the end of the dry season was expected, since the vegetation is subjected to a greater period of water stress, which conditions a higher deposition of these fractions (Figure 4). As observed by Godinho et al. (2013), in Submontane Semideciduous Seasonal Forest, the highest contribution of litter occurred in the dry season.

Regarding the nutrient contents of the L fraction, a standard was observed for the N contents (Table 2), which is attributed to the differentiated composition of the environments' tree species. Studies conducted by Diniz et al. (2015) in forests in the same region show a greater number of tree species belonging to the Fabaceae family. The species that make up this family have the capacity of biological $\mathrm{N}$ fixation. Thus contributing to the entry of this element in quantity in the convex landform.

On the other hand, the higher levels of $\mathrm{P}$ observed in the concave landform may be related to the low mobility of this nutrient in the soil and to the sediment accumulation process in environments with these characteristics. Borém and Ramos (2002) state that the amount of $\mathrm{P}$ and $\mathrm{K}$ in the litter is comparable to the amount of these elements available in the first ten centimeters of the soil, with $\mathrm{K}$ being a nutrient that is easy to move in the plant and in the soil.

For the SS, the distribution of $\mathrm{N}$ contents (Table 3) is directly explained by the presence of $\mathrm{N}$-fixing species and thus corroborating with the L and RM contribution pattern in these environments, since it is the fractions that contribute most to the return of nutrients and easier transformation to release them.

The highest levels of $\mathrm{P}$ and $\mathrm{K}$ were observed in the SS with lower accumulation of water and higher occurrence of erosive processes, thus, higher nutrient content in the litter (F) (Table 3). Studying the contribution of litter in Secondary Atlantic Forest, Ferreira et al. (2014) concluded that nutrient cycling in forest fragments was shown to be dependent on litter production. This is related to rainfall and environmental radiation conditions.

The high values of nutrients observed at the end of the rainy season (Figure 5) are related to the greater amount of new and green leaves, constituting the contributed material, due to the mechanical effect of precipitation and wind. Thus, slope conditions variations and the topographic gradient of the SS were determinant in the contribution and litter nutrient content (Table 3), because they indirectly influence the intensity of the weather agents. In general, SS inserted in the environments with the highest incidence of light and lower accumulation of water were the ones that presented the greatest contribution and nutrient contents.

Additionally, nutrient cycling is also influenced by the leaf fraction because it represents almost $90 \%$ of the deposited litter and it is the component with the highest nutrient content. Thus, it is the fraction responsible for the highest nutrient return to the soil, being the process accelerated by the high specific surface of the leaves in relation to the other litter fractions (GODINHO et al., 2013).

The values found in this study for the annual nutrient return are compatible with studies done by Machado et al. (2015), in the same region, where the $\mathrm{N}$ annual return average was the highest with $51.38 \mathrm{~kg} \mathrm{ha}^{-1}$. Both follow the same pattern observed by Diniz et al. (2015), in the Atlantic Forest also in the same region, in which nutrient return was quantified between $93.18-267.69 \mathrm{~kg}$ of $\mathrm{N} ; 11.67-26.17 \mathrm{~kg}$ of $\mathrm{P}$ and $26.03-53.90 \mathrm{~kg}$ of $\mathrm{K}$.

In this study, the highest levels of $\mathrm{N}$ and $\mathrm{K}$ were observed at the end of the rainy season and at the beginning of the dry season. Under such conditions the environments still offer favorable conditions to vegetation development, which reflects in leaves with higher nutrient contents. The influence of climatic conditions on litter nutrient contents was also observed by Aprile et al. (2013), contrary to the standard observed in this study, the highest nutrient contents in litter were contributed during the dry season to the Amazon Forest environmental conditions.

On the other hand, the differentiated pattern found for P contents (Figure 5) was observed in periods when climatic conditions are not limiting factors for the development and growth of vegetation, and also because $\mathrm{N}$ and K. Studies by Vital et al. (2004), evaluating the production of forest litter in Riparian Zones, verified that $\mathrm{P}$ presented the same pattern. Thus, the amount contributed and the nutrient contents of litter vary according to soil conditions, population density, the age of individuals and species' ability to absorb, use and redistribute nutrients (CUNHA NETO et al., 2013). 
As it can be observed in environments where there is variation of relief conditions and climatic variability, the vegetation presents a different pattern regarding the amount and quality of the litter provided. This knowledge is has relevant importance for decision-making related to the conservation and preservation of these environments, as well as in the definition of vegetation recovery strategies, when necessary.

\section{CONCLUSIONS}

- The contribution and nutrient content of litter are influenced by the type of landform on the slopes of the Mar de Morros region, with forest cover of the Seasonal Submontane Semidecidual Forest type.

- The different types of relief (landforms) associated with rainfall and temperature influence directly in the quantity control and nutritional quality of the litter, with greater contribution in the dry season.

- In both landforms, the highest amount contributed by litter occurs in the small sites of the lower and middle thirds.

- The litter nutrient contents are influenced by the landform and the seasons, with higher levels for the convex landform and rainy season.

\section{REFERENCES}

ALVARES, C. A.; STAPE, J. L.; SENTELHAS, P. C.; GONÇALVEZ, J. L. M.; SPAROVEK, G. Köppen's climate classification map for Brazil. Meteorologische Zeitschrift, Stuttgart, v. 22, n. 6, p. 711 - 728, 2013.

ANTONELI, V.; FRANCISQUINI, V. M. Influência de alguns dados meteorológicos na produção de serapilheira na FLONA (Floresta Nacional) de Irati - Paraná. Ambiência, Paraná, v.10, Suplemento 1, p. 267 $-280,2014$.

APRILE, F.; SIQUEIRA, G. W.; DARWICH, A.J.; SANTOS, V. C.; RIBEIRO, A. A. Concentration of nutrients in litter as a function of soil type, climate and forest composition in Amazon. Agriculture Science Developments, Dadaab, v. 2, n. 8, p. 59-66, 2013.

BASNET, K. Effect of topography on the pattern of trees in Tabonuco (Dacryodes excelsa) dominated rain forest of Puerto Rico. Biotropica, Gainesville, v. 24, p. 31-42, 1992.

BORÉM, R. T.; RAMOS, D. P. Variação estacional e topográfica de nutrientes na serapilheira de um fragmento de Mata Atlântica. Cerne, Lavras, v. 8, n. 2, p. 42-59, 2002.

CUNHA, G. C.; GRENDENE, L. A.; DURLO, M. A.; BRESSAN, D. A. Dinâmica nutricional em Floresta Estacional Decidual com ênfase aos minerais provenientes da deposição da serapilheira. Ciência Florestal, Santa Maria, v. 3, n. 1, p. 35-64, 1993.

CUNHA NETO, E. V.; LElES, P. S. S.; PEREIRA, M. G.; BELlUMATH, V. G. H.; AlONSO, J. M. Acúmulo e decomposição da serapilheira em quatro formações florestais. Ciência Florestal, Santa Maria, v. 23, n. 3, p. 379-387, 2013.

DINIZ, A. R.; MACHADO, D. L.; PEREIRA, M. G.; BALIEIRO, F. C.; MENEZES, C. E. G. Biomassa, estoques de carbono e de nutrientes em estádios sucessionais da Floresta Atlântica, RJ. Agrária, Recife, v. 10, n. 3, p. 443-451, 2015.

EISENLOHR, P. V.; ALVES, L. F.; BERNACCI, L. C.; PADGURSCHI, M. C. G.; TORRES, R. B.; PRATA, E. M. B.; SANTOS, F. A. M.; ASSIS, M. A.; RAMOS, E.; ROCHELlE, A. L. C.; MARTINS, F. R.; CAMPOS, M. C. R.; PEDRONI, E.; SANCHEZ, M.; PEREIRA, L. S.; VIEIRA, S. A.; GOMES, J. A. M. A.; TAMASHIRO, J. Y.; SCARANELlO, M. A. S.; CARON, C. J.; JOLY, C. A. Disturbances, elevation, topography and spatial proximity drive vegetation patterns along an altitudinal gradient of a top biodiversity hotspot. Biodiversity and Conservation, New York, v. 22, n. 12, p. 2767 - 2783, 2013.

FERREIRA, M. L.; SILVA, J. L.; PEREIRA, E. E.; LAMANO-FERREIRA, A. P. N. Litter fall production and decomposition in a fragment of Secondary Atlantic Forest of São Paulo, SP, Southeastern Brazil. Revista Árvore, Viçosa, v. 38, n. 4, p.591-600, 2014.

GODINHO, T. O.; CALDEIRA, M. V. W.; CALIMAN, J. P.; PREZOTTI, L. C.; WATZLAWICK, L. F.; AZEVEDO, H. C. A.; ROCHA, J. H. T. Biomassa, macronutrientes e carbono orgânico na serapilheira 
depositada em trecho de floresta Semidecidual Submontana, ES. Scientia Forestalis, Piracicaba, v. 41, n. 97 , p. 131-144, 2013.

HARA, M.; HIRATA, K.; FUJIHARA, M.; OONO, K. Vegetation structure in relation to micro-landform in an evergreen broad-leaved forest on Amami Ohshima Island, south-west Japan. Ecological Research, Tóquio, v. 11 , p. 325-337, 1996.

INSTITUTO BRASILEIRO DE GEOGRAFIA E ESTATÍSTICA. 2012. Manual Técnico da Vegetação Brasileira: Sistema fitogeográfico Inventário das formações florestais e campestres, técnicas e manejo de coleções botânicas, procedimentos para mapeamentos. IBGE 2a Edição. Rio de Janeiro, 271 p., 2012.

LOPES, M. I. M.; DOMINGOS, M. \& VUONO, Y.S. Ciclagem de nutrientes. In: SYLVESTRE, L.S. \& ROSA, M.M.T. Manual metodológico para estudos botânicos na Mata Atlântica. Seropédica, RJ: EDUR, p. 72 - 90. 2002.

MACHADO, D. L.; PEREIRA, M. G.; CORREIA, M. E. F.; DINIZ, A. R.; SANTOS, L. L.; MENEZES, C. E. G. Ciclagem de nutrientes em diferentes estágios sucessionais da mata atlântica na bacia do Rio Paraíba do Sul, RJ. Biosci J., Uberlândia, v. 31, n. 4, p. 1222 - 1237, 2015.

MENEZES, C. E. G.; PEREIRA, M. G.; CORREIA, M. E. F.; ANJOS, L. H. C.; PAULA, R. R. SOUZA, M. E. Aporte e decomposição da serapilheira e produção de biomassa radicular em florestas com diferentes estágios sucessionais em Pinheiral, RJ. Ciência Florestal, Santa Maria, v. 20, n. 3, p. 439 - 452, 2010.

MOSER, G.; LEUSCHNER, C.; HERTEL, D.; GRAEFE, S.; SOETHE, N.; IOST, S. Elevation effects on the carbon budget of tropical mountain forests (S Ecuador): the role of the belowground compartment. Global Change Biology, Illinois, v. 17, p. 2211 - 2226, 2011.

PEREIRA, M. G.; MENEZES, L. F. T.; SCHULTZ, N. Aporte e decomposição da serapilheira na Floresta Atlântica, Ilha da Marambaia, Mangaratiba, RJ. Ciência Florestal, Santa Maria, v. 18, n. 4, p. 443 - 454 , 2008.

SANTOS, G. L.; PEREIRA, M. G.; LIMA, S. S.; CEDDIA, M, B.; MENDONÇA, V. M. M.; DELGADO, R. C. Landform curvature and its effect on the spatial variability of soil atributes, Pinheiral - RJ/BR. Cerne, Lavras, v. 22, n. 4, p. $431-438,2016$.

SANTOS, G. L.; PEREIRA, M. G.; DELGADO, R. C.; MORAES, L. F. D. Padrões da Regeneração Natural na Região de Mar de Morros, Pinheiral-RJ. Floresta e Ambiente, Seropédica, v. 24, 11 p., 2017.

SCORIZA, R.; PIÑA-RODRIGUES, F. C. M. Influência da precipitação e temperatura do ar na produção de serapilheira em trecho de Floresta Estacional em Sorocaba, SP. Floresta, Curitiba, v. 44, n. 4, p. 687 - 696 , 2014.

SCORIZA, R. N.; PEREIRA, M. G.; PEREIRA, G. H. A.; MACHADO, D. L.; SILVA, E. M. R. Métodos para coleta e análise de serrapilheira aplicados a ciclagem de nutrientes. Série Técnica (Floresta e Ambiente), Seropédica, v. 2, n. 2, p: 01 - 18, 2012.

TEDESCO, M. J.; GIANELLO, C.; BISSANI, C. A.; BOHNEN, H. \& VOLKWEISS, S.J. Análises de solo, plantas e outros materiais. Boletim técnico, n. 5. 2 ed. Porto Alegre: UFRS. 174 p. 1995.

TROEH, F.R. Landform equations fitted to contour maps. Soil Science Society American Journal, Madison, v. 263, p. 616 - 627, 1965.

VILLA, E. B.; PEREIRA, M. G.; ALONSO, J. M.; BEUTLER, S. J.; LELES, P. S. S. Aporte de serapilheira e nutrientes em áreas de restauração florestal com diferentes espaçamentos de plantio. Floresta e Ambiente, Seropédica, v. 23. n. 1, p. 90 - 99, 2016. 